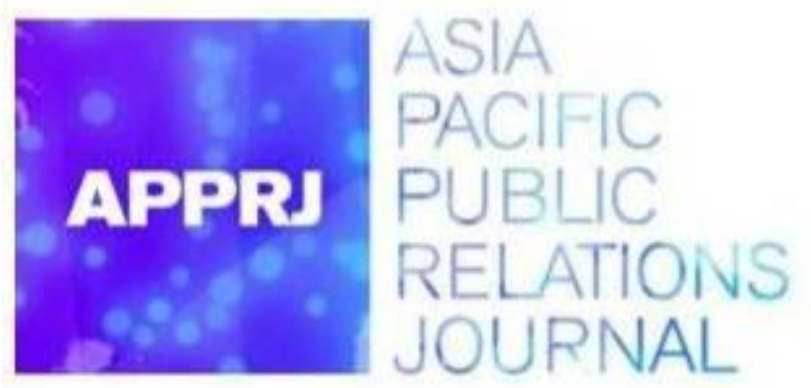

\title{
Newspaper advertising for public relations practitioners during the Malaya era 1957-1963
}

Chang Peng Kee, Universiti Kebangsaan Malaysia, Malaysia

Mohammed Fadel Arandas, Universiti Kebangsaan Malaysia, Malaysia (PhD candidate)

Sivasangari Genapathy, Taylorê̊ University, Universiti Kebangsaan Malaysia (PhD candidate)

Syed Arabi Idid, International Islamic University Malaysia, Malaysia

\begin{abstract}
The very first recruitment for a public relations practitioner in Malaysia was encountered in 1948 and was advertised by the federal government of the British Colony in Malaya. This paper examines the subsequent advertisements after Malaya sought independence from the British colonial government. A total of eleven recruitment advertisements were found before the formation of Malaysia on the $16^{\text {th }}$ September 1963. This paper outlines the advertisers, the titles of positions, as well as their qualifications and duties. The results show that the job requirement mainly came from the federal and local governments. Generally, the duties were related to information services and some specific responsibilities.
\end{abstract}

\section{Keywords}

public relations; advertising; Straits Times; Malaya 


\section{Introduction}

The very first recruitment for public relations practitioners in Malaysia occurred in 1948 with an advertisement by the federal government of British colony in Malaya. This paper examines the subsequent advertisements to track the development of public relations practice in Malaysia with the aim of understanding its nature after Malaya sought independence from the British colonial government. A total of eleven recruitment advertisements were found before the formation of Malaysia on 16 September 1963. This paper outlines the advertisers, the titles of positions, as well as their qualifications and duties. The result shows that the job requirements mainly came from the federal and local governments. Generally, the duties were related to information services and some specific responsibilities.

Every country has its own history of growth in public relations. While some countriesôpublic relations field developed after World War II, other countries have practiced public relations as an occupation even before the war. Many scholars have pointed out that leading Asian countries like Singapore, Taiwan and Japan had major American influence on their public relations practices (LEtang, 2007). However, Malaysia adopted the practices and policies from the United Kingdom based on the British colonial system and the establishment of an information office and public relations department by the British government in Malaya. The historical and technological advancement of Malaysia in politics is strongly associated with the growth of public relations in the country.

In 1957 during the independence and in 1959 when the country was preparing to hold its first ever general election nationwide, the Department of Information Services was given the responsibility to educate people on their rights and responsibilities as citizens. They also organised campaigns to educate people on the voting process (Bashir, n.d). Due to the rise of nationalism and series of political, social and economic growth, there was a strong need for personnel and trained professionals in the field of public relations (Idid, 2014).

Consequently, the need to recruit public relations professionals has emerged. The objective of this study is to study the historical development of public relations practice by studying the advertisements placed in newspapers after the independence. This study therefore will highlight how the recruitment process developed through newspaper advertisements from 1957 to 1963.

\section{Literature review}

\section{Public relations before the independence of Malaya}

Malaysia was under the British colonial rule from the late 18th century until the Japanese occupation from 1942 to 1945. After the World War II, the Malay Peninsula which was ruled by the British as the Federation of Malaya and achieved its independence in 1957. Public relations in this country was introduced through British colonial rule. The Malayan Information Agency was established in 1910 by the British

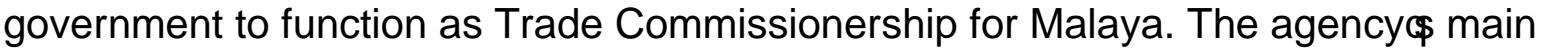
objective was to provide information to attract trades and exports to Malaya. This therefore suggests that public relations activities were carried out even before World War II. In 1926, the Information Agency for Malay States was created to carry out 


\section{Newspaper advertising for public relations practitioners during the Malaya era 1957-1963}

some of the public relations activities for the government (Department of Information, n.d.).

The Department of Information was formed in 1939 in the then-British controlled Malaysia to serve as the press bureau for the government and its many departments. Veteran journalist from Straits Times, George L. Peet, was appointed as the first director of the department. The department was seen necessary to function as a media channel for Britain and its colonies to share news and information. In addition, the Ministry of Information was founded in 1939 by the British war cabinet to face the challenges of war in Europe and to heighten its propaganda in other parts of the world. In 1940 the Department of information and Publicity was established under the leadership of Dr. Victor Purcell incorporating the functions of the former Department of Information functions (Idid, Arandas \& Chang 2016).

This department was mainly established with the objective of reinstating the image of the British government which had been badly affected by the Japanese occupation. Its main portfolios were to release official information, expand general war publicity, disseminate news through government departments, and to work together with the Ministry of Information in London and in Singapore.

Since its formation, this department has been entrusted with various public relations responsibilities including disseminating information to various public to calm and control situations. These activities were carried out through face-to-face communication, print materials required by various government departments, and radio broadcast (Department of Information, n.d.)

The Department of Publicity and Printing was dissolved in April 1946 and given a new name as the Department of Public Relations. The department was mandated to carry out its duties with more functionality that benefitted the locals. The main task of the department was to persuade the locals on British $\hat{\mathbf{s}}$ position in the World War II which propagated Britain $\hat{\Phi}$ preparation to counter-attack India, to re-establish law and order that had been affected by nationwide riots after the defeat of the Japanese, and to plan and execute campaigns that advocated farming crops to overcome food shortages. Above all, the department was given the mandate to be a liaison between the government and the general public in the country (Department of Information, n.d.) because, there were many locals who were still English language illiterate and the British administration was not conversant with the localsôlanguage or customs. Thus, staff members in the Public Relations Department were relied upon to interpret and convey government messages and gather public reactions and public opinion on issues of concern (Ismail \& Ahmad, 2015).

\section{Public Relations after the Independence of Malaya}

Before the independence of Malaya in 1957, public relations activities were focussed on creating awareness among locals of the militant communism that had emerged during the emergency. The Department of Information played a vital role during this era (Selamat \& Rosli, 2015).

The period from Independence (1957) to the formation of Malaysia (1963) highlights two important junctures which are the emergency period (1948-1960) and formation of Malaysia (Idid, 1998). Another important achievement to be noted in this period is the establishment of the Institute of Public Relations Malaysia (IPRM) in 


\section{Newspaper advertising for public relations practitioners}

during the Malaya era 1957-1963

1962 under the Registrar of Society with the sole purpose to promote the interests of public relations practitioners that help enhance public relations practices in the country.

As Idid (2005) stated, the IPRM ǿalvanised to nurture the growth of public relations in the countryô It was a landmark event for public relations professionals in this country that promoted professional development. It enhanced the development of public relations as a profession in its own capacity. Also, it represented a huge step in making public relations practice in this country a true profession.

Another significant event that showcased the value of public relations in Malaya was when the country faced confrontation (1962-1963). The conflict was started with

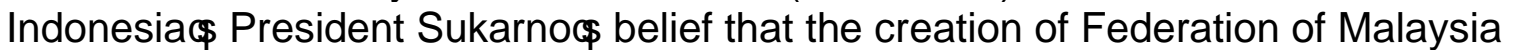
was a plot made by the British to maintain colonial rule behind the independence granted to her former colony. The new Malaysia had to engage in propaganda campaigns at both national and international levels. The Director-General of Department of Information, DatoôMohd. Sopiee Ibrahim travelled all over Malaysia to brief officers of the department on the development of the event. The department initiated the setup of mobile units to keep the public especially the rural people informed and not to fall prey to the accusations and propaganda made by Indonesia. The department also organized mass gatherings to disseminate information and awareness on anti-Sukarno gatherings (Selamat \& Rosli, 2015).

Moving forward, the function of public relations changed significantly from oneway communication (to ónformô to more two-way communication (to óbtainô. Public relations professionals who worked under the Department of Information were given a new challenge to garner people $\hat{\Phi}$ support and engagement to execute government programmes. Given the multiracial nature of Malaysia, it was the department $\hat{\Phi}$ main portfolio to instil the sense of harmony and unity among the different races through various campaigns (Ismail \& Ahmad, 2015).

The Ministry of Information and Broadcasting was formed in 1961. It was placed under the Prime Minister $\hat{\mathbf{s}}$ Departments under the leadership of the then prime minister, Tunku Abdul Rahman Putra Al-Raj with Syed Jaafar Albar as his junior minister (Department of Information, n.d.). At this juncture, the Department of Information was placed under the purview of the Ministry of Information. The new independent country also saw many policies implemented by the government which was stimulated by the growth of mass media. In return, this paved the way for the growth of advertising and public relations in the country. This perhaps was a notable milestone for the public relations sector in Malaysia taking its step forward to the future utilising the mass media. The development of mass communication that influenced the advent of PR from a regular vocation to a profession was enabled through the media, especially the newspaper that organisations and government agencies used to address. The public and advertisements were used by organisations and government agencies as vehicles to specify and identify the right personnel for their recruitment. Hence newspaper advertisements were useful indicators of public relations growth in the public sphere (Idid, Arandas \& Chang 2016). 


\section{Methodology}

There are many ways to study the development of public relations. However, Idid, Arandas \& Chang (2016) stated that $\phi 0]$ ne is able to discern the growth of public relations skills and expertise unless a historical approach is conducted to understand such a phenomenon. ôGoing by the norm that public relations personnel are hired by organisations and those organisations advertise their job openings in newspapers, this study discusses how advertisements for public relations appeared in The Straits Times newspaper from the year of 1957 to 1963 to collect data. The time frame was from the Independence Day on 31 August 1957 to formation of Malaysia on 16 September 1963. A content analysis of selected advertisements from The Straits Times was conducted to examine how public relations profession was advertised during the stipulated time period.

Those advertisements that had public relations positions advertised were gathered to collect data. Keywords were used in the searching process. The term q́ublic relationsôwas keyed in the search icon and retrieved the result of almost 2530 related stories between 1957-1963. By narrowing down the search through focusing on advertisements related to public relations recruitment, a total of 11 advertisements were found within the period of study. The result showed 11 advertisements of all editions of The Straits Times, advertised for the position.

\section{Results and Discussion}

The first mention of ñpublic relationsòin The Straits Times was made on 29 March, 1939. It was placed on page 5 as an announcement of a talk in England by Major General, J. H. Beith, Director of Public Relations at the War Office. Even though the term q́ublic relationsôwas already in use in Malaysian press in 1939, there was no mention of the term or any designation related to public relations until later in 1948 (Idid, Arandas \& Chang 2016).

The position of public relations gradually changed after Independence in 1957. Between Independence in 1957 until the formation of Malaysia in 1963, a total of 11 recruitment advertisements about PR were found. Interestingly, out of 11 advertisements, 10 were advertised by the public sector and only one was advertised by the private sector. This shows that the public sector recognised the need for public relations personal more than the private sector. The results of this study showed that there was a difference in job title, and job specification, which included qualification, duties, and salaries.

According to the current study, the first mention of public relations was on 14 October 1957, about two months after Independence (31st August 1957). The advertisement was posted by the prime minister $\hat{\Phi}$ department for the position of press secretary.

In relation to the position title, three departments advertised for a position of Фublic Relations Officersôwhich was published on 13th August 1962, 8th September 1962, and 8th October 1962. It is notable that the term oublic relationsôappeared in these advertisements and gained popularity after the advent of IPRM in 1962. Another, two advertisements used the title \$enior Liaison Officerôwhich were published on 8th June 1961 and $27^{\text {th }}$ August 1963. Other advertised positions were titled as \$ublic Relations \& Cultural Affairs Officerôon 1st November 1958, \$olice Information Officerôon 6th October 1959, థublic Relations and Information Officerô 


\section{Newspaper advertising for public relations practitioners during the Malaya era 1957-1963}

on 12th September 1959, dnformation Officerôpublished on 25th January 1960, Đress Secretaryôon 14th October 1957, and \&iaison Officerôon 8th June 1961.

It is notable that some positions were titled after the department $\hat{\mathbf{s}}$ name or the

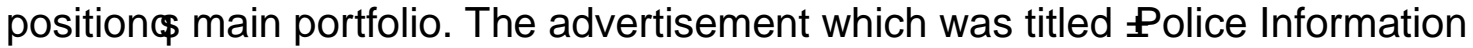
Officerôwas advertised by the Royal Federation of Malay police. Some of the duties listed for this position included arranging interviews with individual police officers when requested by newspapers or newspaper correspondents, editing of the Malayan Police Magazine, and handling the membership of the committee responsible for the production of police publication ®engamanô Similarly, the position titled \$ublic Relations and Cultural Affairs Officerôwhich was advertised by the Ministry of Education required applicants to have a sound interest in cultural matters to handle the cultural affairs in the ministry.

The results showed some leniency in the requirement for education qualifications. A total of seven advertisements required a university degree. While most of the positions required candidates to possess a degree from University Malaya or a diploma from Raffles College or other equivalent qualification, some positions only required candidates to possess minimum education qualification. For the position of \$olice Information Officerôadvertised by Royal Federation of Malay Police, and ciaison Officerôposition advertised by the Federation of Malaya Government (Information Services) candidates were required to only possess a school certificate with a credit scored in English language. But the candidates needed to have minimum of 7 to 10 yearsôexperience in the fields of public relations or journalism. The advertisement for a senior level dnformation Officerôposition advertised by the Central Electricity Board, stated that candidates must obtain post-school academic qualification without stating the level.

Another interesting finding was that the advertisement posted by the British Import House for the position đublic Relations Officerôonly required a ógood personalityô no education qualifications were mentioned. However, almost all of the advertisements required candidates to possess language proficiency in English, Malay, or other vernacular languages. To some extent, educational qualifications have been substituted with experience and other job centric requirements. All the 11 advertisements required experience except the advertisement on 8th October 1962 by a British import house for the position of Đublic Relations Officerô

As for the duties, there were many common duties mentioned across these advertisements. Some of the common duties identified included preparing speeches, writing press releases, feature articles and press statements, arranging and conducting press conferences. Press Secretary at the prime minister $\hat{\Phi}$ department required showcasing good knowledge of world affairs. Additional duties for a Public Relations and Cultural Affairs Officer in the Ministry of Education included interpreting education policy to non-English speaking public, and showcasing good knowledge of different cultures, intelligence to communicate and assimilate various functions of the ministry. The additional duties of a \$enior Liaison Officerôat the Federal of Malaya included undertaking media relations. This job required a candidate to lead the press monitoring section in addition to dealing with and handling foreign journalists.

Pre-independence advertisements had a clear hierarchy of organisational positions. Candidates were able to identify their position level within the organisation with clear salary grading. In contrast, most of the advertisements in this study period 
did not have a clear hierarchy except for advertisements posted by the Federation of Malaya in 1961 and 1963 for the position of \$enior Liaison Officerôwhich indicated the level of position as a đ́eadô

There was no salary grading. The result of the current study shows there were differences in salary for married and bachelor candidates. Married men with a family were offered higher salary than bachelors for the same position. Candidates with degree or diploma qualifications were offered the same salary as a candidate with lesser academic qualifications if their experience in the field was suitable. A press secretary at the prime minister⿳亠丷厂 department and senior liaison officer with a meadô position was offered the same salary package of \$891-A28-1.087 with a cost of living allowance. This shows that title of a position or academic qualification was not a sole determinant factor for a salary package; but that it may be based on the complexity of the job. Being in the prime minister $\hat{\mathbf{s}}$ department, the press secretary was required to have knowledge of the entire government system, national and international affairs. Generally, most of the jobs offered cost of living allowance. Only one job advertisement which was posted by the Central Electricity Board for the position d́nformation Officerôimposed a minimum of one-year probation period.

From the result of this study, the advertisement posted by the British Import House for the position of Public Relations Officerôwas the only one that is not in sync with other advertisementsôeducational requirements, duties and salary package. There was no specification stated for duties and candidates, besides having a good personality, and a requirement to have good connections in broadcasting and an interest in music. Even though the commencing salary is offered at $\$ 350$, they were offered an annual increment and entertainment expenses.

\section{Conclusion}

The current study provided a better understanding on the development of public relations by tracing the job requirements in public and private sectors through newspaper advertisements. It is also an insightful way to understand how public relations job requirements evolved from pre-independence Malaysia. It is notable that various factors have contributed to the development of public relations in Malaysia. The intense development in politic, economic, and technology must be given credit as it created the awareness and demand for the public relations roles in the country. The advent of the IPRM also has had an impact on the development of the public relations profession in this country. It is only after the advent of the IPRM that the professional development of public relations was made possible in Malaysia. Analysing advertisements on public relations positions has given insight on the organisational requirements for each position. The indication of salary structure, job specifications, and educational requirement provided job applicants a clear direction on their career path.

\section{References}

Adnan, M. H. (2010). Government \& political public relations: an introduction. Seri Kembangan, Selangor, Malaysia: University Publication Centre.

Bashir, F. (n.d). Technological transformation in the Malaysian public relations - An analytical study on the status of public relations in Malaysia. [Weblog]. Retrieved 20 December 2018, from 
https://www.academia.edu/7004722/Technological_Transformation_in_the_M alaysian_Public_Relations_An_Analytical_Study_on_the_Status_of_Public_R elations_in_Malaysia

History, (n.d). Department of Information. Retrieved from https://www.penerangan.gov.my/index.php/en/about-us/history?start=6

Idid, S. A. (1998). Beauty, brain and brawn in public relations. Bangi, Selangor: Universiti Kebangsaan Malaysia.

Idid, S. A. (2005). Institute of Public Relations Malaysia: A historical perspective. International Islamic University Malaysia: International Islamic University Malaysia, 2005.

Idid, S. A. (2014). The past and coming communication journey in Malaysia. Malaysian Journal of Communication, 30(30), 1-16.

Idid, S. A., Arandas, M. F., \& Chang P. K. (2016). Recruiting the public relations officer during British colonial Malaysia. IUKL International Postgraduate Colloquia (IIPC 2016), Infrastructure University Kuala Lumpur 578-587.

Ismail, T. A \& Ahmad. J. H. (2015). Public relations vs advertising. Malaysian Journal of Communication, 2(31), 117-130.

LđEtang, J. (2007). Public relations concepts practice and critique. London: Sage Publications Ltd.

Selamat, M. R. \& Rosli, M. R. (2015). Orientations of government public relations practice in Malaysia: A pre-independence and post-colonialism perspectives. International Journal of Liberal Arts and Social Science, 3(7), 1-10. 